\title{
ON EXPONENTIAL CONVEXITY FOR POWER SUMS AND RELATED RESULTS
}

\section{J. PeČARić AND AtiQ UR ReHMAN}

Abstract. In this paper, we use parameterized class of increasing functions to give exponential convexity of the non-negative difference of certain inequality as a function of parameter in connection with power sums. We define new means of Cauchy type and give its relation to the means defined in [5] and [6]. Also we give related mean value theorems of Cauchy type.

Mathematics subject classification (2010): 26D15, 26D20, 26D99.

Keywords and phrases: convex functions, log-convex functions, power sums, mean value theorems.

\section{REFERENCES}

[1] N. I. AKHIEZER, The classical moment problem and some related questions in analyisis, Oliver and Boyd Ltd. The University Press, Glasgow 1965.

[2] M. ANWAR, J. JAKŠEtiĆ, J. PeČARIĆ AND ATIQ UR RehmAn, Exponential convexity, positive semidefinite matrices and fundamental inequalities, J. Math. Inequal. 4, 2 (2010), 171-189.

[3] S. N. Bernstein, Sur les fonctions absolument monotones, Acta Math. 52 (1929), 1-66.

[4] J. Pečarić, F. Proschan and Y. L. Tong, Convex functions, Partial Orderings and Statistical Applications, Vol. 187 of Mathematics in Science and Engineering, Academic Press, Boston, Mass, USA, 1992.

[5] J. PeČARIĆ AND ATIQ UR RehmAn, On Logarithmic convexity for power sums and related results, J. Inequal. Appl., 2008, Article ID 389410, (2008), 9 pp.

[6] J. PeČARIĆ AND ATIQ UR REHMAn, On Logarithmic convexity for power sums and related results II, J. Inequal. Appl., 2008, Article ID 305623, (2008), 12 pp.

[7] D. V. WIDDER, The laplace transform, Princeton 1941, 1946. 